\title{
Regeneracja bitumicznych nawierzchni drogowych modyfikatorami otrzymywanymi z surowców ekologicznych
}

\author{
Michal Babiak $^{1}$, Maria Ratajczak ${ }^{2}$, Jacek Kosno ${ }^{3}$ \\ ${ }^{1}$ Instytut Konstrukcji Budowlanych, Wydział Budownictwa i Inżynierii Środowiska, \\ Politechnika Poznańska, e-mail: michal.babiak@put.poznan.pl \\ ${ }^{2}$ Instytut Konstrukcji Budowlanych, Wydział Budownictwa i Inżynierii Środowiska, \\ Politechnika Poznańska, e-mail: maria.ratajczak@put.poznan.pl \\ ${ }^{3}$ Instytut Ciężkiej Syntezy Organicznej ,,Blachownia' w Kędzierzynie-Koźlu, \\ e-mail: kosno.j@icso.com.pl
}

Streszczenie: Wykorzystanie granulatu asfaltowego do produkcji mieszanek mineralno-asfaltowych jest technologią powszechnie znaną i stosowaną na szeroką skalę w wielu krajach Unii Europejskiej. Prym w tej dziedzinie wiodą Holendrzy, Niemcy i Duńczycy. W Polsce regulacje prawne umożliwiają stosowanie w mieszankach mineralno-asfaltowych dodatek granulatu asfaltowego w ilości do 30\%. Wprowadzenie uniwersalnego dodatku do destruktu asfaltowego, który poprzez zmianę parametrów reologicznych lepiszczy, zwiększy jego adhezje, umożliwi zastosowanie zwiększonej ilości granulatu asfaltowego w mieszance mineralno-asfaltowej.

Słowa kluczowe: asfalt, granulat asfaltowy, nawierzchnia drogowa, regeneracja.

\section{Wprowadzenie}

Budowa nawierzchni drogowych o podwyższonej trwałości zmęczeniowej przy zastosowaniu materiałów z recyklingu jest szczególnie istotna ze względu na rosnące natężenie ruchu samochodowego oraz wzrost obciążenia osi pojazdów. Zaniedbania ze strony zarządców dróg w zakresie utrzymania i ich naprawy doprowadzają do szybszego zniszczenia nawierzchni. Obecnie stosowane metody naprawy, przebudowy i przystosowania do aktualnych warunków ruchu infrastruktury drogowej (o nawierzchni asfaltowej) wymagają frezowania starej i zniszczonej warstwy. Pozyskana w ten sposób mieszanka mineralnoasfaltowa nazywana jest destruktem asfaltowym, a ten po przetworzeniu i określeniu parametrów technicznych granulatem asfaltowym. Stosowanie granulatu asfaltowego do mieszanek mineralno-asfaltowych jest zgodne z polityką Unii Europejskiej, która jest ukierunkowana na zapobieganie powstawania odpadów. Ochrona środowiska, stosowanie materiałów recyklingowych oraz obniżenie kosztów inwestycji drogowych są podstawowymi kryteriami stosowanymi w nowoczesnym, zrównoważonym budownictwie drogowym.

\section{Recykling nawierzchni drogowych}

Głównym materiałem używanym do produkcji mieszanki mineralno-asfaltowej jest kruszywo naturalne - stanowi ono około 90-95\% całości mieszanki. Jego pozyskiwanie niekorzystnie wpływa na środowisko naturalne. Budowa i eksploatacja kopalń surowców drogowych powoduje nieodwracalną degradacje środowiska naturalnego. Dodatkowym 
źródłem zanieczyszczenia środowiska jest emisja spalin z silników samochodów przewożących kruszywo drogowe do wytwórni mas bitumicznych.

Remonty dróg o nawierzchni asfaltowej wymagają frezowania starej i zniszczonej warstwy, wskutek czego powstaje odpad w postaci destruktu asfaltowego. Nawierzchnia poddana recyklingowi może być ponownie wykorzystana do produkcji mieszanek mineralno-asfaltowych. Umożliwia to skuteczne i bezpieczne zagospodarowanie odpadów oraz ogranicza zapotrzebowanie na kruszywa naturalne. Zgodnie z obowiązującymi w Polsce przepisami 1 możliwe jest stosowanie w mieszankach mineralno-asfaltowych granulatu asfaltowego w ilości do $20 \% \mathrm{w}$ „metodzie na zimno” oraz do $30 \% \mathrm{w}$ „metodzie na gorąco”. Proces recyklingu można wykonać na miejscu (recykling in situ) lub w wytwórni mas bitumicznych (recykling in place). Recykling wykonywany w wytwórni mas bitumicznych pozwala na dokładne dozowanie materiału oraz kontrolę składu nowopowstałej mieszanki mineralno-asfaltowej, zminimalizowany jest również wpływ warunków atmosferycznych.

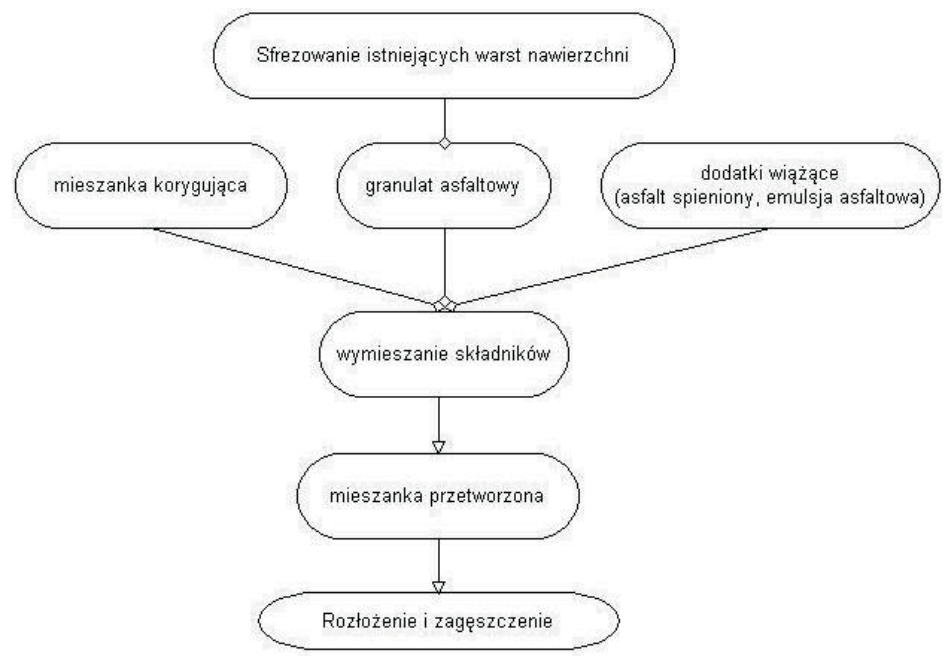

Rys. 1. Schemat recyklingu na miejscu 2

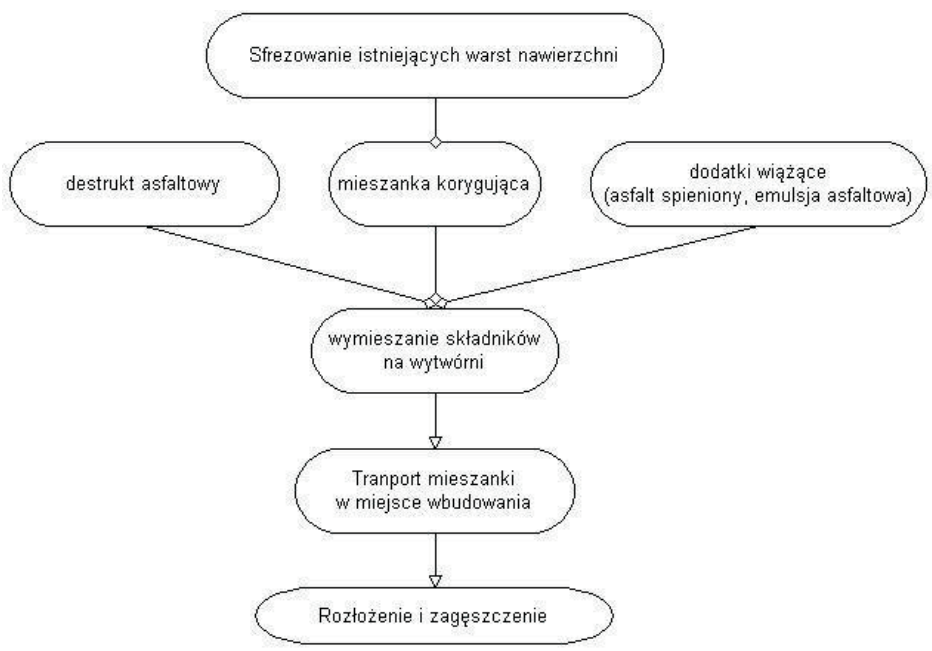

Rys. 2. Schemat recyklingu w wytwórni mas bitumicznych 2 
Pomimo iż są to technologie powszechnie znane i stosowane w Europie, to na polskim rynku jedynie 0,2 \% wbudowywanych mieszanek mineralno-asfaltowych zawiera w swoim składzie granulat asfaltowy, gdzie w sąsiednich Niemczech ponad $60 \%$ nowych nawierzchni wykonywana jest $\mathrm{z}$ zastosowaniem recyklingowego materiału, jakim jest granulat asfaltowy 3 .

Tabela 1. Wykorzystanie destruktu asfaltowego w nowych mieszankach mineralno-asfaltowych 3

\begin{tabular}{|c|c|c|c|c|c|c|c|c|}
\hline \multirow[b]{3}{*}{ Kraj } & \multicolumn{8}{|c|}{ Rok } \\
\hline & \multicolumn{2}{|c|}{2010} & \multicolumn{2}{|c|}{2012} & \multicolumn{2}{|c|}{2013} & \multicolumn{2}{|c|}{2014} \\
\hline & $\begin{array}{c}\text { Dostępność } \\
\text { destruktu } \\
\text { asfaltowego, } \\
\text { Mg }\end{array}$ & $\begin{array}{c}\text { MMA z } \\
\text { udziałem } \\
\text { destruktu, } \\
\% \\
\end{array}$ & $\begin{array}{c}\text { Dostępność } \\
\text { destruktu } \\
\text { asfaltowego, } \\
\text { Mg }\end{array}$ & $\begin{array}{c}\text { MMA z } \\
\text { udziałem } \\
\text { destruktu, } \\
\% \\
\end{array}$ & $\begin{array}{c}\text { Dostępność } \\
\text { destruktu } \\
\text { asfaltowego, } \\
\mathrm{Mg}\end{array}$ & $\begin{array}{c}\text { MMA z } \\
\text { udziałem } \\
\text { destruktu, } \\
\% \\
\%\end{array}$ & $\begin{array}{c}\text { Dostępność } \\
\text { destruktu } \\
\text { asfaltowego, } \\
\mathrm{Mg}\end{array}$ & $\begin{array}{c}\text { MMA z } \\
\text { udziałem } \\
\text { destruktu, } \\
\% \\
\end{array}$ \\
\hline Austria & 500000 & - & 750000 & - & 750000 & - & 1500000 & - \\
\hline Belgia & 1500000 & 47 & 1500000 & 49 & 1500000 & 51 & 1500000 & - \\
\hline Czechy & 1650000 & 10 & 1400000 & 10 & 1450000 & 10 & 1600000 & - \\
\hline Dania & 350000 & 39 & 580000 & 47 & 790000 & 58 & 1300000 & - \\
\hline Finlandia & 1000000 & 65 & 1000000 & 65 & 860000 & 20 & 1000000 & - \\
\hline Francja & 7080000 & - & 6500000 & $>60$ & 6900000 & $>65$ & 9243000 & - \\
\hline Niemcy & 14000000 & 60 & 11500000 & 97 & 11500000 & - & 10900000 & - \\
\hline Węgry & 44580 & 10 & 100777 & 46 & 88000 & 20 & 20000 & - \\
\hline Islandia & 15000 & 2,5 & 15000 & 2,5 & 15000 & 3,0 & 15000 & - \\
\hline Irlandia & 100000 & 2,0 & 150000 & 10 & 150000 & - & - & - \\
\hline Włochy & 11000000 & - & 10000000 & - & 10000000 & - & 9000000 & - \\
\hline Holandia & 4000000 & 67 & 4000000 & 73 & 4500000 & 70 & 4500000 & - \\
\hline Norwegia & 750000 & 8 & 787689 & 13 & 686268 & 20 & 837410 & - \\
\hline Polska & 110000 & 0,2 & 100000 & 0,2 & - & - & - & - \\
\hline Rumunia & 40000 & $<5$ & 20000 & 5,0 & 22000 & 10 & 20000 & - \\
\hline Hiszpania & 1590000 & 11 & 368000 & 6,4 & 205000 & 1,3 & 390000 & - \\
\hline Szwecja & 1100000 & 60 & 1000000 & 70 & 900000 & 70 & 1200000 & - \\
\hline Szwajcaria & 1450000 & 21 & 1575000 & 24 & 1370000 & 27 & 1000000 & - \\
\hline Turcja & 2420000 & 10 & 3816000 & 1 & 1200000 & 1 & 2340000 & - \\
\hline
\end{tabular}

W Polsce największym ograniczeniem stosowania nowych rozwiązań i technologii są precyzyjne przepisy techniczne, a zwłaszcza specyfikacje techniczne dotyczące budowy nawierzchni bitumicznych. Obecnie Wymagania Techniczne WT-2 2014 ograniczają stosowanie granulatu asfaltowego do mieszanek mineralno-asfaltowych do 30\%. Dokument ten zawiera wytyczne technologiczne obowiązujące podczas fazy projektowej procesu budowlanego. Pomimo, że warunki techniczne umożliwiają stosowanie granulatu asfaltowego podczas przebudowy, naprawy i budowy dróg, to specyfikacje techniczne sporządzane przez inwestorów (zarządców dróg) często odrzucają takie rozwiązania. Obawy przed niską jakością proponowanych rozwiązań są nieuzasadnione, czego dowodem jest powszechność tego typu rozwiązań w krajach zachodnich (Niemcy, Szwecja, Holandia, Dania, Belgia).

Realizowane w Polsce naprawy dróg w okresie 2008-2012 „wyprodukowały” ok. $1420000 \mathrm{Mg}$ destruktu asfaltowego 3. Zakładając utrzymanie intensywności remontów 
drogowych na tym samym poziomie przez najbliższe lata oraz zwiększenie udziału destruktu asfaltowego w nowo wbudowywanych nawierzchniach, można znacząco ograniczyć wydobycie kruszywa naturalnego oraz degradacje środowiska naturalnego.

\section{Zmiany właściwości fizycznych asfaltów w wyniku procesów starzenia}

Lepiszcza zawarte w destrukcie mają pogorszone właściwości użytkowe. Jest to spowodowane zmianami w składzie i w strukturze chemicznej asfaltu. Wraz z upływem czasu asfalt staje się bardziej sztywny, zwiększa się jego lepkość oraz temperatura mięknienia, a obniża penetracja i ciągliwość. Największy wpływ na zmianę właściwości lepiszcza ma zwiększenie zawartości grup polarnych i oddziaływanie między nimi prowadzące do asocjacji oraz kondensacji i polimeryzacja mniejszych jednostek struktury z utworzeniem struktur o większym ciężarze cząsteczkowym.

W wyniku procesów starzenia w asfalcie zachodzą zmiany struktury chemicznej. Są one wynikiem reakcji tlenu z powietrza z reaktywnymi cząsteczkami w asfalcie. Powstałe produkty utleniania mogą oddziaływać między sobą oraz wchodzić w reakcje z innymi cząsteczkami polarnymi obecnymi w asfalcie 4. Promotorami utleniania są substancje tworzące łatwo wolne rodniki. Energia potrzebna do utworzenia wolnych rodników może być dostarczana przez ogrzanie asfaltu lub pochodzić od promieniowania słonecznego 4. Dlatego w podwyższonej temperaturze rodnikowe reakcje utleniania asfaltu przebiegają $\mathrm{z}$ dużą szybkością. Wolne rodniki inicjują reakcje polimeryzacji w asfalcie, wskutek czego zwiększa się jego masa cząsteczkowa. Tlen cząsteczkowy może także wchodzić w reakcje ze związkami zawierającymi wiązania nienasycone bez uprzedniego utworzenia wolnego rodnika 4. Jest to wynikiem występowania w strefie podwójnego wiązania, zwiększonego pola elektrycznego.

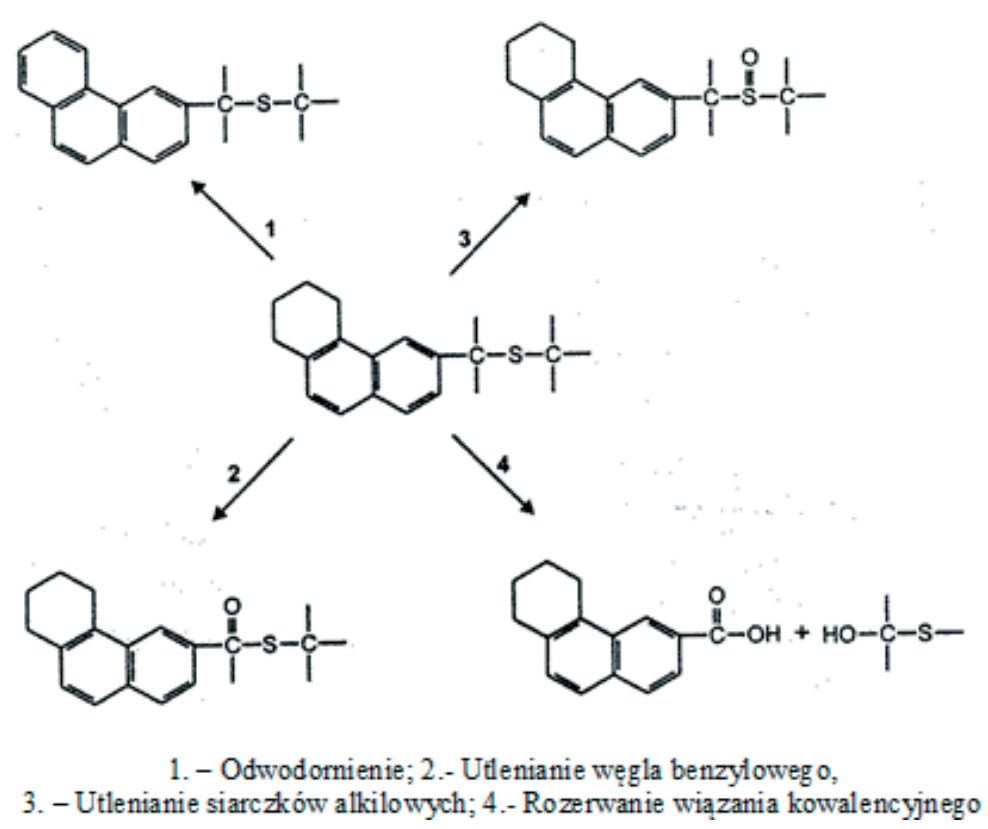

Rys. 3. Wpływ utleniania na zmiany w strukturze chemicznej asfaltu 5 
Najważniejsze reakcje chemiczne zachodzące podczas procesu starzenia przedstawiono na Rys 4. i są to:

- Odwodornienie - odłączenie wodoru za pomocą tlenu z utworzeniem wody i połączenia nienasyconego; w asfaltach zachodzi najczęściej odwodornienie pierścieni naftenowych do pierścieni aromatycznych, które ulegają kondensacji tworząc struktury policykliczne.

- Utlenianie węgla benzylowego do grupy karbonylowej; węgiel benzylowy jest bardzo podatny na utlenianie.

- Utlenianie siarczków alkilowych do sulfotlenków; następuje konwersja obojętnych atomów siarki do silnie polarnych grup $S=0$, które mają znaczny wpływ na twardnienie asfaltu.

- Rozerwanie wiązania kowalencyjnego w cząsteczce i utworzenie kwasu organicznego.

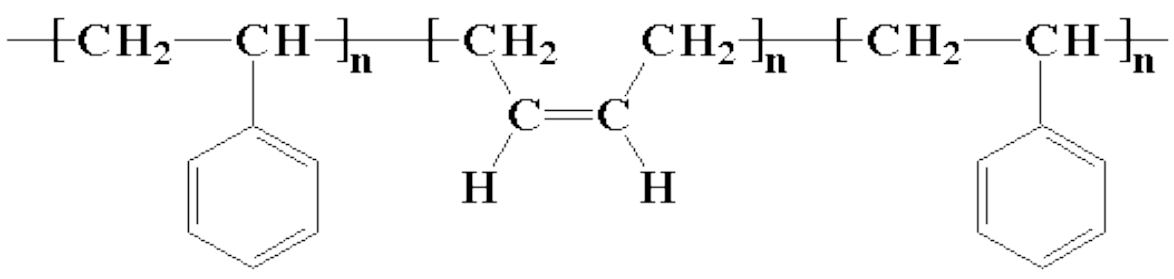

Rys. 4. Wzór strukturalny SBS (styren-butadien-styren 6

Głównymi produktami utleniania asfaltu są ketony i sulfotlenki. W pierwszym etapie utleniania asfaltu w podwyższonej temperaturze, reakcja tworzenia się ketonów jest dominująca 5. W niższej temperaturze, przeważa powstawanie sulfotlenków. Siarczki są bardziej reaktywne niż inne związki znajdujące się w asfalcie, zatem ulegają najłatwiej utlenieniu. Dopiero po utlenieniu większości siarczków zachodzi utlenianie węgla benzylowego, a jako produkty otrzymuje się związki zawierające grupy karbonylowe. Około 95\% tych związków stanowią ketony, reszta to kwasy karboksylowe i ich bezwodniki. Największe stężenie ketonów występuje we frakcjach żywic i asfaltenów 5.

Starzenie lepiszcza wpływa na jego przyczepność do materiału mineralnego. Zmniejszenie mobilności cząsteczek asfaltu wskutek asocjacji i ich częściowe unieruchomienie w pobliżu powierzchni kruszywa zmieniają w znacznym stopniu adhezję. Kwasy karboksylowe, których ilość zwiększa się podczas starzenia asfaltu, są silnie adsorbowane na powierzchni kruszywa i łatwo wypierane z niej przez wodę, przez co przyczyniają się do zniszczenia nawierzchni. Ponadto na skutek zachodzących procesów starzeniowych w lepiszczu wzrasta temperatura łamliwości asfaltu.

\section{Fizyczna modyfikacja asfaltu}

W celu poprawy parametrów termoplastycznych i właściwości reologicznych lepiszczy oraz w celu spowolnienia procesu starzenia asfaltów stosuję się różnego rodzaju modyfikatory. Obecnie stosowane dodatki do asfaltów to różnego rodzaju polimery - substancje niereagujące chemicznie z asfaltem. Polimery pełnią rolę wypełniacza lub tworzą wewnątrz asfaltu przestrzenną sieć - tzw. sieciowanie fizyczne. Wybrane typy polimerów termoplastycznych można zastosować do modyfikacji asfaltów. Plastomery termoplastyczne (EVA, EMA, APP, EPDM) modyfikując asfalt nie tworzą w nim wewnętrznej sieci, pełnią role wypełniacza. Po wprowadzeniu do układu koloidalnego asfaltu stanowią odrębne, niezwią- 
zane między sobą cząstki. W efekcie następuje zwiększenie lepkości i sztywności układu. W niskich temperaturach zwiększenie sztywności nie powoduje poprawy zdolności odkształcenia sprężystego. Elastomery tworzą wewnątrz asfaltu przestrzenną sieć - tzw. sieciowanie fizyczne. Do najczęściej wykorzystywanych elastomerów należą kopolimery styrenowo-butadienowe o strukturze nieuporządkowanej.

W drogownictwie, jak i przy produkcji materiałów hydroizolacyjnych, najczęściej stosowanym modyfikatorem bitumów jest SBS (styren-butadien-styren). Zauważa się istotny wpływ modyfikatora na poprawę właściwości w niskich temperaturach, przy jednoczesnej poprawie właściwości $\mathrm{w}$ wysokich temperaturach, znacznie poszerza się zakres lepkosprężysty asfaltu 7,8 . Jednak, aby uzyskać pożądany efekt w mieszance mineralnoasfaltowej, konieczna jest modyfikacja na poziomie do $5 \%$. Na podstawie badań własnych zaobserwowano negatywny wpływ modyfikatora tego typu na odporność asfaltu na starzenie. Jest to efekt implikacji starzenia „czystego” asfaltu i polimeru.

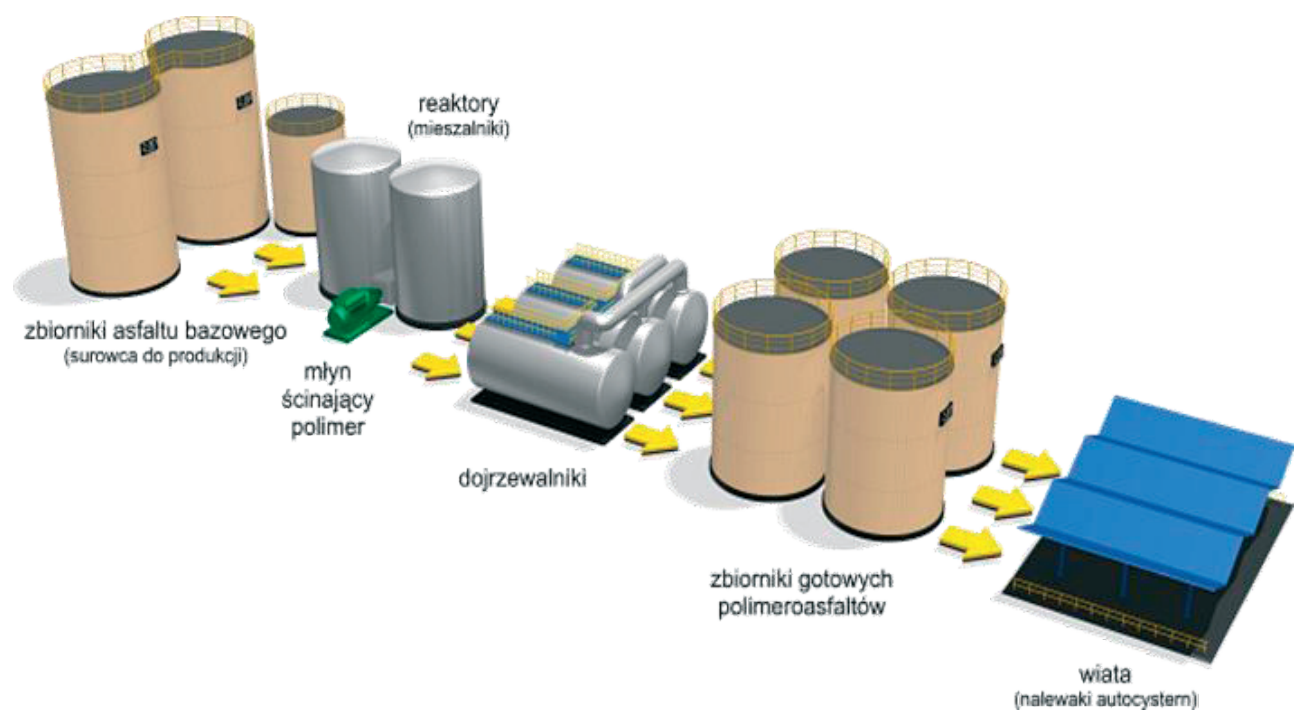

Rys. 5. Schemat procesu modyfikacji asfaltu polimerami 9

Łączenie polimeru $\mathrm{z}$ asfaltem wymaga użycia specjalnych młynów oraz przebiega w wysokiej temperaturze. Jest to proces energochłonny i czasochłonny. Należy zwrócić uwagę, że podczas mieszania składników asfalt narażony jest na starzenie technologiczne. Wysoka temperatura oraz intensywne mieszanie wzmagają i przyspieszają proces utleniania asfaltu. W tych warunkach konwencjonalne antyutleniacze są nieskuteczne, gdyż w temperaturze powyżej $180^{\circ} \mathrm{C}$ utlenianie asfaltu nie ma mechanizmu wolnorodnikowego.

\section{Chemiczna modyfikacja asfaltu}

Drugą, ważną grupą modyfikatorów są substancje, które wchodzą w reakcje chemiczną $\mathrm{z}$ asfaltem, przez co powstaje trwały $\mathrm{w}$ czasie $\mathrm{i}$ temperaturze związek. Zachodząca reakcja chemiczna gwarantuje lepszą kompatybilność dodatku $\mathrm{z}$ asfaltem, w porównaniu z modyfikatorami oddziaływującymi na asfalt tylko w sposób fizyczny. Przykładem takiego modyfikatora są imidazoliny. 
Imidazoliny zalicza się do związków heterocyklicznych. Składają się one z pięcioczłonowego pierścienia, w którym są umiejscowione dwa atomy azotu. Imidazoliny zawierają w swej strukturze pierścień 4,5-dihydro1H-imidazolu.

W zależności od podstawnika w pozycji 2 pierścienia wyróżnia się formy tautomeryczne 10 :

- podstawnik w postaci wodoru lub o charakterze węglowodoru,

- podstawnik zawierający związaną z pierścieniem grupę - $\mathrm{SH},-\mathrm{OH}$, -NH4 lub podstawioną grupę aminową -NHR.

Wyróżnia się dwa podstawowe typy imidazolin:

- Imidzoliny typu I

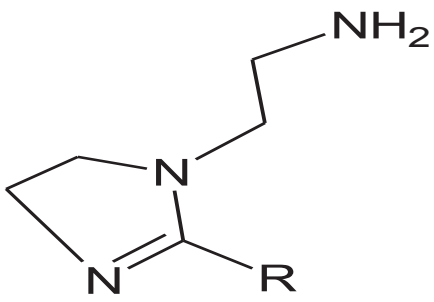

Rys. 6. Schematyczny wzór strukturalny imidazoliny typ I 10

- Imidazoliny typu II

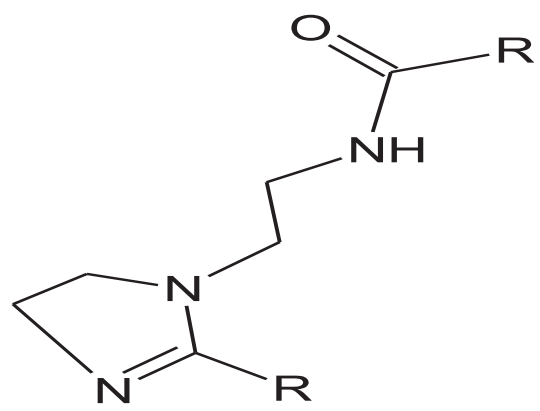

Rys. 7. Schematyczny wzór strukturalny imidazoliny typ II 10

Struktura niezawierająca wiązania podwójnego w pierścieniu nosi nazwę imidazolidyny. Imidazoliny należą do szerokiej grupy związków powierzchniowo czynnych, wyróżnia się imidazoliny kationowe i imidazoliny amfoteryczne.
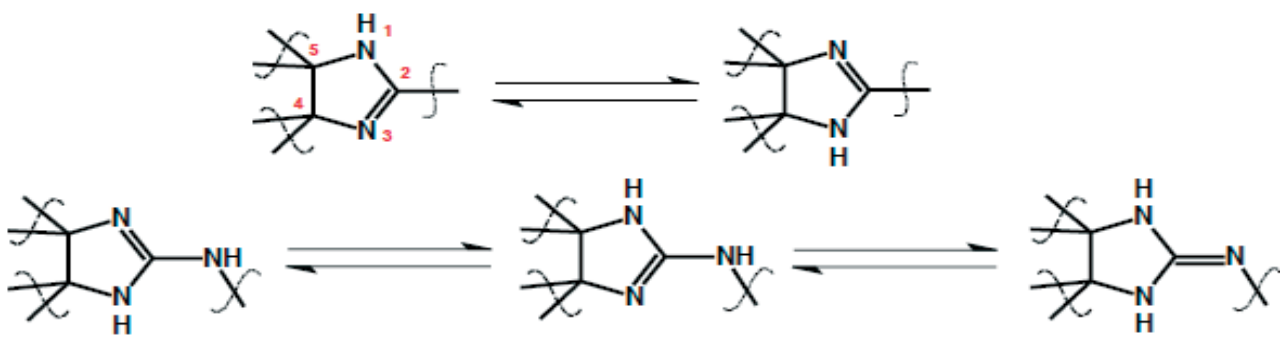

Rys. 8. Tautomeria pierścienia imidazoliny oraz 2-iminoimidazolidyny 10 


\section{Wyniki wstępnych badań laboratoryjnych}

Do badań wstępnych wykorzystano asfalt drogowy 160/220 wyprodukowany przez rafinerię PKN Orlen S.A. w Płocku oraz imidazoliny otrzymane w Instytucie Ciężkiej Syntezy Organicznej „Blachownia” w Kędzierzynie Koźlu. Warunki techniczne WT-2 nie dopuszczają wykorzystania asfaltu 160/220 do budowy warstwy ścieralnej, jednak za względu na szereg wcześniejszych badań wykonanych na tym lepiszczu, autorzy zdecydowali się na przeprowadzenie badań wstępnych na asfalcie 160/220. W przypadku uzyskania oczekiwanych wyników projekt badawczy będzie kontynuowany na lepiszczach stosowanych przy produkcji nawierzchni asfaltowych.

Próbki asfaltów (,czystych” i modyfikowanych) poddano testom, określając ich temperatury łamliwości metodą Fraassa $\left(T_{F r}\right) 11$ oraz przyczepność do kruszywa bazaltowego zgodnie z normą 12 .

W tabeli 2 oraz na rys. 9 przedstawiono wyniki badań temperatury łamliwości badane metodą Fraassa $\left(T_{F r}\right)$ asfaltu „czystego” i modyfikowanego imidazoliną. Podane wyniki są średnią arytmetyczną z dziesięciu pomiarów. Dla wszystkich próbek asfaltów poddanych modyfikacji odnotowano wprost proporcjonalny spadek parametru. Najniższą wartość temperatury łamliwości odnotowano modyfikując asfalt imidazoliną rzepakowej typu I (spadek o 58,7\% w stosunku do asfaltu bez modyfikacji).

Utleniony asfalt zawarty $\mathrm{w}$ destrukcie cechuję się wysoką temperaturą łamliwości, przez co staję się kruchy i podatny na spękania. Z obawy przed szkodami mrozowymi, pęknięciami i zniszczeniami niskotemperaturowymi (w polskim klimacie odnotowuję się ok 150 cykli przejścia temperatury przez „,0”) ogranicza się zastosowanie destruktu zawierającego utleniony i usztywniony asfalt w nowych nawierzchniach. Dodatek imidazoliny do asfaltu działa regenerująco - obniża temperaturę łamliwości. Poprawa elastyczności asfaltu w niskich temperaturach umożliwia dodanie większej ilości destruktu do mieszanki mineralno-asfaltowej, bez pogorszenia jej parametrów.

Tabela 2. Temperatura łamliwości asfaltów modyfikowanych imidazoliną

\begin{tabular}{lccccc}
\hline & $\begin{array}{c}\text { Procentowa } \\
\text { zawartośc } \\
\text { Lodyfikatora } \\
\text { (wagowo) }\end{array}$ & $\begin{array}{c}\text { Asfalt 160/220 } \\
+ \text { imidazolina } \\
\text { rzepakowa typu I }\end{array}$ & $\begin{array}{c}\text { Asfalt 160/220 } \\
+ \text { imidazolina } \\
\text { rzepakowa typu II }\end{array}$ & $\begin{array}{c}\text { Asfalt 160/220 } \\
+ \text { imidazolina } \\
\text { smalcowa typu I }\end{array}$ & $\begin{array}{c}\text { Asfalt } 160 / 220 \\
+ \text { imidazolina } \\
\text { smalcowa typu II }\end{array}$ \\
\hline 1. & $0,0 \%$ & $-16,2$ & $-16,2$ & $-16,4$ & $-16,2$ \\
\hline 2. & $0,5 \%$ & $-17,7$ & $-16,6$ & $-17,5$ & $-16,3$ \\
\hline 3. & $1,0 \%$ & $-18,7$ & $-17,8$ & $-18,2$ & $-17,5$ \\
\hline 4. & $1,5 \%$ & $-19,6$ & $-18,6$ & $-19,1$ & $-18,3$ \\
\hline 5. & $2,0 \%$ & $-21,2$ & $-19,4$ & $-20,5$ & $-19,1$ \\
\hline 6. & $2,5 \%$ & $-22,1$ & $-20,9$ & $-21,2$ & $-21,5$ \\
\hline 7. & $3,0 \%$ & $-24,0$ & $-21,8$ & $-23,3$ & $-23,2$ \\
\hline 8. & $4,0 \%$ & $-25,4$ & $-23,8$ & $-25,4$ & $-23,8$ \\
\hline 9. & $5,0 \%$ & $-25,7$ & $-25,1$ & $-25,8$ & \\
\hline
\end{tabular}

Na rys. 10 przedstawiono wyniki badań przyczepności do kruszywa bazaltowego asfaltu „czystego" i modyfikowanego imidazoliną. Dla wszystkich próbek asfaltów poddanych modyfikacji odnotowano wzrost przyczepności. Największy przyrost uzyskano dla próbek asfaltów modyfikowanych imidazoliną rzepakową typu I w ilości 5\% (o 60,9\%). 


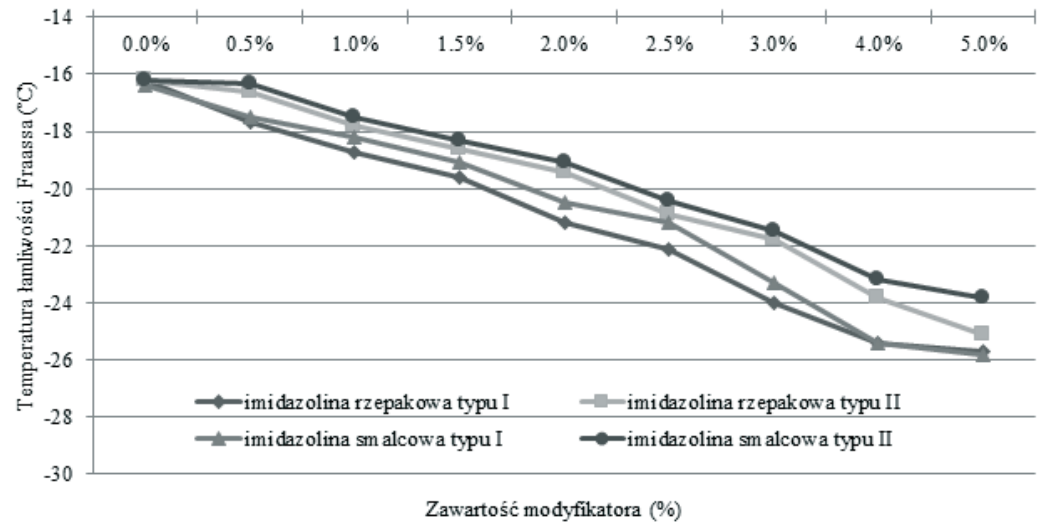

Rys. 9. Temperatura łamliwości asfaltów modyfikowanych imidazoliną

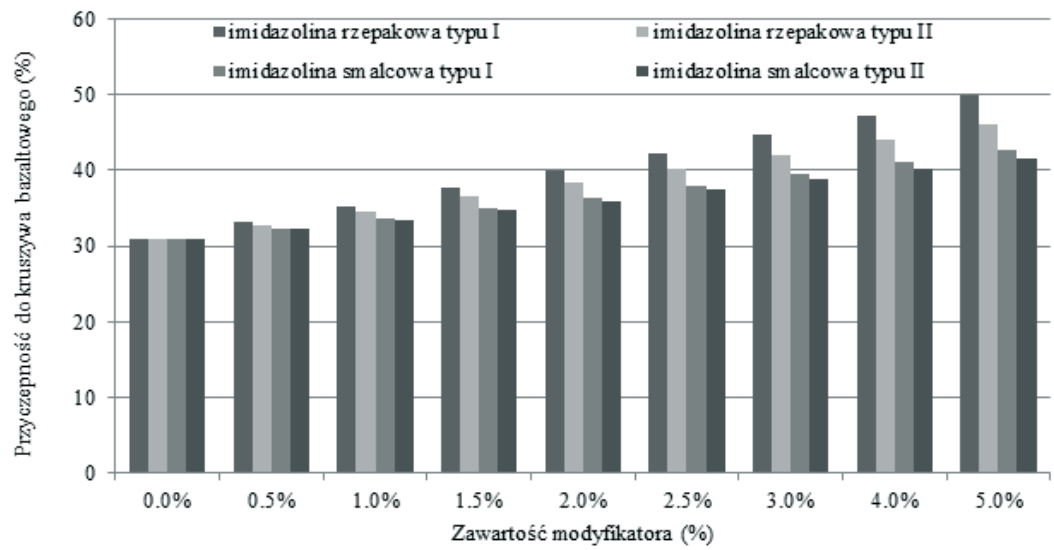

Rys. 10. Przyczepności do kruszywa bazaltowego asfaltów modyfikowanych imidazoliną techniczną

\section{Podsumowanie}

Wstępne badania wykazały, że już niewielki dodatek imidazolin znacznie poprawia adhezję asfaltów do podłoża (do 60\%) oraz ma istotny wpływ na zmianę jego temperatury łamliwości, co poszerza zakres lepkosprężysty lepiszcza.

Źródłem przewagi proponowanego rozwiązania w stosunku do obecnie stosowanych jest wprowadzenie uniwersalnego dodatku do destruktu asfaltowego, który poprzez zmianę parametrów reologicznych lepiszczy, zwiększy jego adhezję umożliwi zastosowanie zwiększonej ilości granulatu asfaltowego w mieszance mineralno-asfaltowej. Możliwość użycia zwiększonej ilości granulatu asfaltowego jest efektem zastosowania dodatku, który regeneruje asfalt, wiąże chemicznie i tworzy $\mathrm{z}$ nim trwały $\mathrm{w}$ czasie i temperaturze związek. Wprowadzenie dodatku podczas naprawy dróg metodą in-situ recyklingu na gorąco umożliwi uzyskanie mieszanki mineralno-asfaltowej o parametrach zgodnych $\mathrm{z}$ warunkami technicznymi obowiązującymi na terenie kraju.

Kolejną zaletą proponowanego rozwiązania jest jego kompleksowe działanie, wynikające z budowy i struktury chemicznej dodatku, co wyeliminuje konieczność stosowania $\mathrm{w}$ trakcie produkcji mieszanki mineralno-asfaltowej innych substancji, takich jak emulgatory czy rozpuszczalniki. 


\title{
Literatura
}

1. Nawierzchnie asfaltowe na drogach krajowych WT - 2. Mieszanki mineralno-asfaltowe. Wymagani techniczne, Warszawa 2014.

2. http://blogdrogowy.blogspot.com/2013/02/recykling-nawierzchni-asfaltowych.html (dostęp czerwiec 2016).

3. European Asphalt Pavement Association. Asphalt in Figures (http://www.eapa.org/promo.php?c=174).

4. Babiak M., Kosno J. Imidazoliny jako modyfikatory asfaltów stosowanych do produkcji materiałów hydroizolacyjnych. Przemysł Chemiczny 4 (2016) 95-98.

5. Gaweł I., Kalabińska M., Piłat J. Asfalty drogowe. Wydawnictwo Komunikacji i Łączności, Warszawa 2001.

6. www.pslc.ws (dostęp czerwiec 2016).

7. Martin J.V., Orange G., Baumgardner G. Performance of road asphalt improved by chemical modification and by combined chemical and polymer modification. Improved rutting and moisture resistance. Revue Generale des Routes et des Aerodromes 843 (2005).

8. Słowik M., Wpływ modyfikacji polimerami na właściwości reologiczne asfaltów drogowych. rozprawa doktorska, Poznań 2001.

9. Błażejowski K., Olszacki J., Peciakowski H. Poradnik asfaltowy 2009. ORLEN Asfalt, Płock 2009.

10. Treder A. P. Synteza oraz właściwości biologiczne pochodnych 4(5)-(2-aminoetylo)imidazoliny. Rozprawa doktorska, Gdańsk 2008.

11. PN-EN 12593 Asfalty i lepiszcza asfaltowe. Oznaczanie temperatury łamliwości metodą Fraassa.

12. PN-EN 12697-11 Mieszanki mineralno-asfaltowe. Metody badań mieszanek mineralnoasfaltowych na gorąco. Część 11: Oznaczanie powinowactwa pomiędzy kruszywem i asfaltem

\section{Regeneration of pavement with modifiers based on ecological materials}

\author{
Michał Babiak $^{1}$, Maria Ratajczak ${ }^{2}$, Jacek Kosno ${ }^{3}$ \\ ${ }^{I}$ Institute of Structural Engineering, Faculty of Civil and Environmental Engineering, \\ Poznan University of Technology,e-mail: michal.babiak@put.poznan.pl \\ ${ }^{2}$ Institute of Structural Engineering, Faculty of Civil and Environmental Engineering, \\ Poznan University of Technology,e-mail: maria.ratajczak@put.poznan.pl \\ ${ }^{3}$ Institute of Heavy Organic Synthesis „,Blachownia” Kędzierzyn-Koźle, \\ e-mail:z.nowacki@pollub.pl
}

\begin{abstract}
The production of the mix asphalt with the feedstock of reclaimed asphalt is very popular technology and widely applied in many countries of European Union. The leaders are Netherland, Germany and Denmark. A polish law regulations allows the manufacture the asphalt mixtures with the content of the feedstock of reclaimed asphalt pavement (RAP) up to $30 \%$. The additive of a universal modifier to the reclaimed asphalt will change the rheological parameters of the bituminous binders, increase the adhesion. The manufacture of the mix asphalt with the larger content of the feedstock of reclaimed asphalt pavement will be possible.
\end{abstract}

Keywords: asphalt, feedstock of reclaimed asphalt pavement, regeneration. 